\title{
Changing Citizen Confidence: Orientations towards Political and Social Institutions in Australia, 1983-2010
}

\author{
Clive Bean*
}

Queensland University of Technology, 2 George Street, Brisbane QLD 4000, Australia

\begin{abstract}
Since the early 1980s, when confidence in institutions was first measured in an Australian academic social survey, Australia - and the world - has faced many political, social and economic changes. From corporate scandals and company collapses, to unprecedented terrorist attacks, to major ongoing international conflicts, to changes in government and all manner of political machinations, to the global financial crisis and its aftermath. One consequence of such developments has been that many major political, social and economic institutions have come under intense pressure. Using survey research data, this paper investigates how public confidence in various Australian institutions and organisations has changed over time. The results are variable and in some instances surprising. Confidence in some institutions has remained high, and in some low, over an extended period of time. In other cases, confidence has varied quite markedly at different time points. As well as looking at trends in the level of public confidence in institutions, the paper examines different dimensions of confidence together with underpinning socio-political factors. It also discusses theoretical and practical implications of the data.
\end{abstract}

Keywords: $21^{\text {st }}$ century, Australia, citizen confidence, institutions, social attitudes, political change.

\section{INTRODUCTION}

Across the world, the pace of political, social and economic change over the last two or three decades has been rapid. As the end of the $20^{\text {th }}$ century loomed, the post-World War II era of progress and growing prosperity had come under increasing strain as economies and the governments overseeing them struggled to cope in the inflationary environment that grew during the 1970s. But as economies recovered, a new period of apparently even greater prosperity emerged.

In Australia at least, however, this new period of growth only seemed to set the scene for repeated corporate scandals and company collapses throughout the 1990s and into the new century (Bean 2005). On top of these events came an era of unprecedented terrorist attacks and major ongoing international conflicts, plus changes of government and various political manoeuvrings, then the global financial crisis of 2007-2008 and its aftermath. Though Australia has been at arms-length from some of these events they have nonetheless had an impact. For example, while Australia resisted the worst effects of the global financial crisis and was seen in the eyes of foreign observers as having been hit very lightly, its impact was still keenly felt by governments, businesses and individuals alike (Sykes 2010; Ciro 2012).

Not surprisingly, such developments have placed considerable pressure on a range of major political, social and economic institutions. The research in this current paper extends earlier work examining public confidence in a

\footnotetext{
*Address correspondence to this author at the Queensland University of Technology, 2 George Street, Brisbane QLD 4000, Australia;

Tel: +61-7-31384512; Email: c.bean@qut.edu.au
}

variety of prominent institutions in Australia (Bean 2003) in order to consider how these institutions have fared in the public mind over a longer period of time. The earlier paper focused on the period between the mid-1980s and the beginning of the $21^{\text {st }}$ century and found, among other things, that confidence in major economic institutions progressively declined over that period. Now data covering a span of over a quarter of a century - from 1983 to 2010 - including a number of more recent time points, will allow such findings to be revisited and reconsidered.

\section{LITERATURE, THEORY AND CONCEPTS}

An important contextual consideration for this study is the pressures exerted on democratic polities and what this has meant for the course of democratic governance over recent decades. Scholarly work in the 1970s and 1980s raised the spectre of a 'crisis of governability' as citizen expectations about what governments could and should deliver rose but frequently remained unfulfilled (King 1975; Rose 1980; Birch 1984). After a period of intense focus, these concerns declined to some extent within the literature and the concentration on challenges to governance gave way to broader concerns in the early years of this century about terrorism, refugees, financial instability and climate change. These developments are in turn linked to concerns about declining civic trust and social capital, the associated pressures on major national and international institutions and the question of how good government can be sustained in the face of citizen expectations and demands.

Some scholars argue that democratic citizens continue to become increasingly critical of and dissatisfied with governmental performance and that the political, economic 
and social realities facing contemporary political regimes constitute significant strains on democratic systems (Braithwaite and Levi 1998; Norris 1999; Warren 1999; Pharr and Putnam 2000). Some work points to this being a phenomenon that has been apparent for a lengthy period (Dalton 1999).The effects of these stresses are apparent not just on elected governments but on a wide range of political, economic and social institutions. Putnam (2000) has argued strongly that the decline in social and political trust seen in many countries is evidence that social capital - the social cement composed of networks, norms and trust that binds communities - is being worn down, a view shared by numerous other authors (Nye, Zelikow and King 1997; Burchell and Leigh 2002; Leigh 2010; Martin 2010).

Related to trust is the notion of confidence (Lipset and Schneider 1983), which is the focus of this paper. At a conceptual or theoretical level, trust and confidence are distinct. Arguably, the essence of trust is a perception of the integrity of persons. With confidence the emphasis is on evaluations of the effectiveness of organisations and institutions in performing their designated roles. Thus one might have trust in the individuals who lead an organisation to execute their duties appropriately and confidence that the organisation will achieve particular goals. Trust is therefore more personal and more about process while confidence is more diffuse and more about performance and outcomes. Trust tends to be in individuals and confidence in organisations. One trusts an individual to do the right thing and has confidence that an organisation or institution will carry out its mission. Confidence, more than trust, also tends to be prospective or forward looking. At an empirical level, however, trust and confidence are closely tied and in general discourse they are often used more or less interchangeably.

In Australia, various writers have investigated confidence, with an early theme being the noticeable decline in public confidence in institutions across the political, social and economic spectrum towards the end of the $20^{\text {th }}$ century (Papadakis 1999; Bean 2003; 2005). Then the trend appeared to stall (Blunsdon and Reed 2010), an observation that only serves to reinforce the desirability of examining more recent data to identify whether a reversal ensued or the decline continued. Other recent work has examined the connection between perceptions of corruption and a limited set of items on confidence, without directly addressing this question (McAllister 2014).

While diverse in their origins and approaches, one theoretical commonality across the different literatures cited above is the likelihood that a decline in confidence in public institutions is inevitable due to citizen expectations combined with critical dissatisfaction. A core question this study sets out to answer is whether, in the Australian context, a range of major political, social and economic institutions have been able to maintain the confidence of the public in the uncertain economic and political climate following the global financial crisis. The above literature would suggest that it may have been difficult for them to do so. The significance of institutional confidence as an indicator of democratic resilience is such that an ongoing decline could have negative consequences for the future of democracy and the functioning of society (Papadakis 1999; Blunsdon and Reed 2010).

\section{DATA AND METHODS}

The analysis to follow employs survey data to address the questions raised in the above discussion. The research moves from broad descriptive analysis, with comparisons over time, to a more intensive analytic investigation using multi variates methods. The initial focus is on the most up-to-date data, which have not been analysed in previous studies, in order to paint a picture of confidence in institutions in the recent period. Table $\mathbf{1}$ depicts confidence levels in a set of Australian political, economic and social institutions using recent data from the Australian Election Study (AES) of 2010 (McAllister et al., 2011). The AES is a national postal survey of voters conducted after each federal election and, although there has been another federal election since 2010 in 2013 - the 2010 data set is the most recent one containing the set of questions on confidence.

Next, the paper adopts a retrospective stance, turning to compare the current levels of confidence with equivalent data from four earlier surveys dating back over more than a quarter of a century to 1983 , asking about all or many of the same institutions, in order to see how confidence has changed. The earlier data are from the World Values Surveys (WVS) conducted in Australia in 1983 and 1995 (Inglehart et al., 2000), the AES of 2001 (Bean, Gow and McAllister 2002) and the Australian Survey of Social Attitudes (AuSSA) of 2003 (Wilson et al., 2005). Methodological issues to consider in comparing these data over time include the timing of the various surveys, with some conducted in the wake of federal elections and others in the middle of the electoral cycle. This is certainly a factor of which to be mindful when considering changes in the items relating to political institutions. There are also minor differences in the wording of some items between the AES and the WVS, on one hand, and the AuSSA, on the other.

In order to explore the data further, factor analysis is then employed to identify key dimensions in the data. These are then subjected to multivariate analysis to determine differences in the socio-economic correlates of confidence in different kinds of institutions, such as political institutions compared to economic institutions.

The core data for the analysis come from a battery of items in which survey respondents were asked about their levels of confidence in fourteen different public and private institutions, using the question: 'How much confidence do you have in the following organisations?' with the following answer categories: 'a great deal of confidence', 'quite a lot of confidence', 'not very much confidence' and 'none at all'.

\section{CONFIDENCE IN INSTITUTIONS IN 2010}

Table 1 contains the data for the 2010 AES, showing the list of institutions in the order in which they were presented to respondents. From a broad perspective, and without focusing on individual institutions initially, the data in Table 1 present a mixed picture. With few exceptions, the numbers of respondents expressing a great deal of confidence in institutions tend to be very small. On the other 
hand, we do not see large numbers expressing a complete lack of confidence, either, although the balance tends to be skewed more towards the negative than the positive end of the scale. For example, only three institutions have a doublefigure $\%$ rating them with a great deal of confidence, while twice that number have a double-figure $\%$ showing no confidence at all. Likewise, if we consider the responses that essentially express confidence - combining a great deal of confidence with quite a lot of confidence - then, again, only three institutions have the confidence of more than $70 \%$ of the sample. Four have around $30 \%$ or less showing confidence and then half of the institutions listed (seven) have a middling proportion showing confidence, with five of them clustering at the lower middle, around 40 to $45 \%$. Only a third (five of the fifteen institutions listed) have more than $50 \%$ expressing a great deal or quite a lot of confidence in them.

Turning to specific institutions, the one that inspires the most confidence - and by quite a margin - is the armed forces: $36 \%$ of the AES sample express a great deal of confidence in the Australian military, with a further 54 saying they have quite a lot of confidence, which gives a total of $90 \%$ expressing a positive response. This puts the armed forces well clear of the next two most highly rated institutions, which are universities and the police. There is slightly more confidence overall in universities than in the police $(80 \%$ express either a great deal or quite a lot of confidence in universities compared to 77 for the police), but the police have more people expressing a great deal of confidence in them $(19 \%)$ than universities $(14 \%)$. After that there is quite a drop to major Australian companies, with $55 \%$ expressing either a great deal or quite a lot of confidence, and the Australian political system, in which 53 $\%$ have a great deal or quite a lot of confidence.
Thus we have a two-tiered group at the top, the armed forces, the police and universities, and then well behind, major Australian companies and the Australian political system. At the bottom of the confidence scale we have the press, television, trade unions and Australian political parties. Of these four, the press sits clearly at the bottom, with only $1 \%$ of the sample indicating they have a great deal of confidence in that institution and $18 \%$ expressing quite a lot of confidence. In other words, some level of confidence is shown in the press by less than a fifth of the sample while nearly a quarter say they have no confidence at all. The press's media colleague, television, does only a little better, with $26 \%$ of respondents expressing some confidence and then come trade unions with $30 \%$ and political parties with $31 \%$. Trade unions rival the press for the proportion expressing complete lack of confidence, with $21 \%$ of the sample giving the 'none at all' response.

Five institutions are on the negative side of the ledger in confidence terms, but less dramatically so and this group is dominated by political institutions: the federal government in Canberra (in which $41 \%$ express a degree of confidence), the public service (42\%) and the federal parliament (44\%). The other two in this group are the legal system (in which 40 $\%$ express confidence) and banks and financial institutions (42\%). Assessments of banks and financial institutions are quite divided, with $15 \%$ of respondents expressing no confidence in them at all.

\section{CHANGING CONFIDENCE}

The ratings in Table 1, while interesting in their own right, raise questions about how various institutions come to be judged with more or less confidence by the Australian public and whether such views have been consistent over the

Table 1. Confidence in institutions in Australia, 2010 (percentages).

\begin{tabular}{|c|c|c|c|c|}
\hline & A great deal of confidence & Quite a lot of confidence & Not very much confidence & None at all \\
\hline The armed forces & 36 & 54 & 8 & 1 \\
\hline The press & 1 & 18 & 57 & 23 \\
\hline Television & 2 & 23 & 58 & 16 \\
\hline The police & 19 & 58 & 20 & 3 \\
\hline The federal government in Canberra & 3 & 38 & 49 & 9 \\
\hline Australian political parties & 2 & 29 & 58 & 11 \\
\hline The federal parliament & 4 & 39 & 48 & 8 \\
\hline Banks and financial institutions & 5 & 37 & 43 & 15 \\
\hline Universities & 14 & 66 & 18 & 2 \\
\hline The Australian political system & 6 & 46 & 39 & 9 \\
\hline
\end{tabular}

Source: Australian Election Study, $2010(\mathrm{n}=2061)$. 
years or whether they have changed and if so how and why. Have the armed forced always been so well regarded and has the press always been viewed so dimly? Do the judgements by the public in 2010 of major companies and of banks and financial institutions represent a rise or decline in public confidence in recent years or do these institutions tend to be rated similarly over lengthy periods of time? Can we identify a general trend towards greater confidence in institutions now than in the past or towards a general diminution in confidence?
Reflecting on the 1983 and 1995 WVS data, Papadakis (1999: 75) noted a 'sharp decline in confidence in governmental and nongovernmental organisations between 1983 and 1995'. The data in Fig. (1) confirm this assessment of the period 1983 to 1995 . In five of the eight institutions common to the 1983 and 1995 surveys confidence dropped sharply, as suggested by Papadakis. These included the legal system, the press, the federal government, the public service and major Australian companies. Confidence also declined in the police, though not sharply, while confidence in the
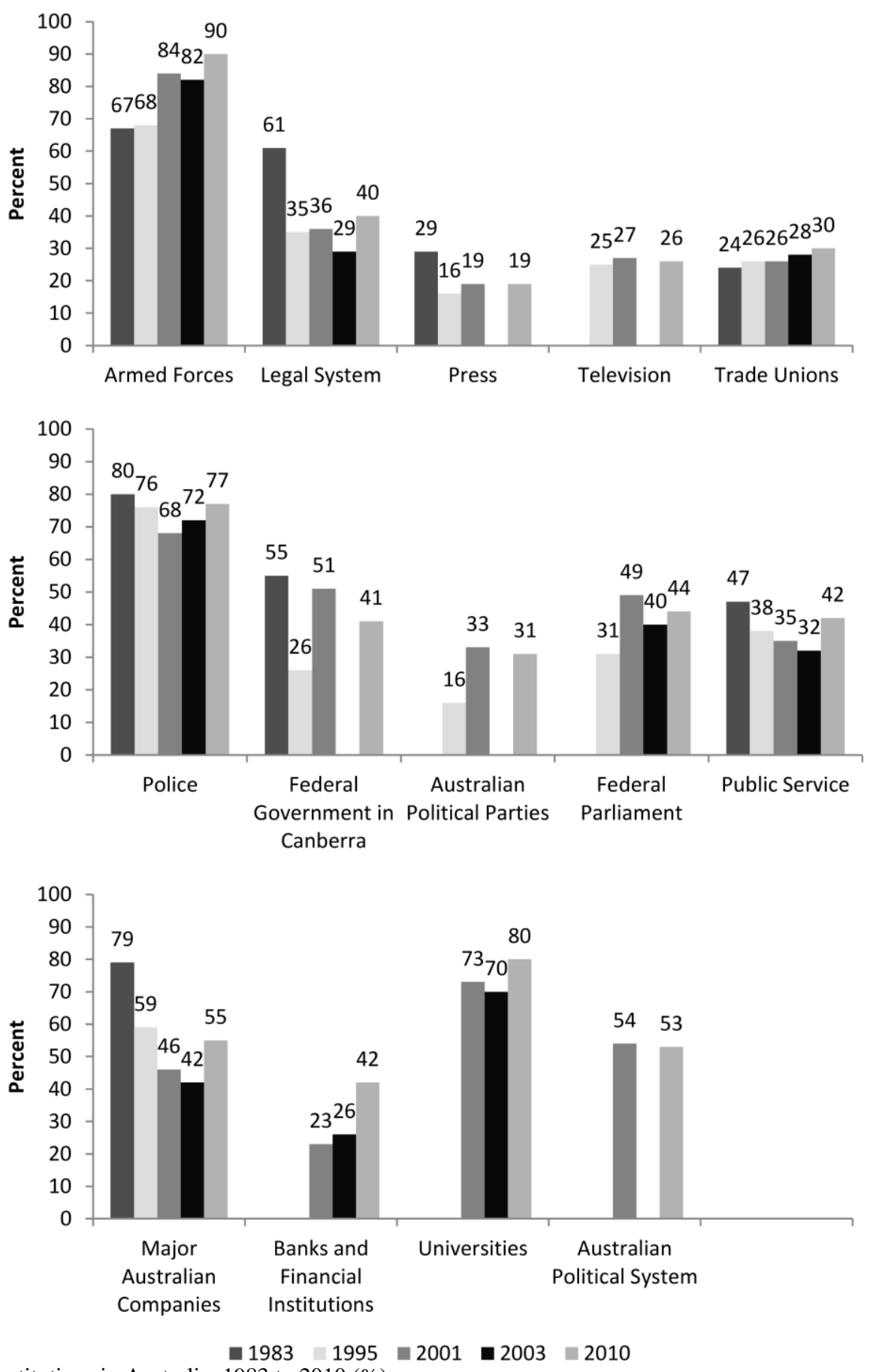

Fig. (1). Confidence in institutions in Australia, 1983 to 2010 (\%).

Sources: World Values Survey, 1983 Australian data (n=1200), 1995 Australian data (n=2048); Australian Election Study, 2001 ( $\mathrm{n}=2010)$; Australian Survey of Social Attitudes, 2003 (n=4270); Australian Election Study, 2010 (n=2061). 
armed forces and in trade unions remained fairly steady, at a high and low level, respectively. There was no measurable increase in confidence between 1983 and 1995 in of any the eight institutions.

A moment's reflection on global developments since then, in relation to the traumas of terrorism, war, financial crises and political upheavals, might lead us to expect a continuing decline in confidence into the $21^{\text {st }}$ century. The data in Fig. (1), however, suggest that this has not been the case. There is in fact no case of an institution suffering unrelenting decline in public confidence over the period from 1983 to 2010. The closest example would be major Australian companies, which initially recorded a high level of confidence (79 \% in 1983) that dropped sharply over the next two decades (to a low of $42 \%$ in 2003) but then climbed again in 2010 (to $55 \%$ ). There are several other examples of institutions experiencing a decline in confidence for a period followed by a rise in the most recent data, including the legal system (which had a sharp drop between the 1980s and 1990s), the police, the public service and universities. Some others show an up and down pattern, including several of the political institutions, while others have fairly consistent confidence levels throughout (the press, after an initial drop, television, trade unions and the Australian political system).

The comparative picture for 2010 is one of relatively strong confidence. For a number of institutions public confidence is on the rise and, for several, 2010 registers the highest confidence level for the time points for which we have readings (the armed forces, trade unions, banks and financial institutions, and universities). However, only the armed forces and, less certainly, financial institutions, exhibit a sustained increase in confidence across the entire period. Other trends that stand out are the consistently high levels of citizen confidence in the armed forces (and apparently trending upwards), the police and universities and, at the other end, the consistently low levels of confidence in the press, television, trade unions and political parties.

The irony of the revelation of improved confidence in major Australian companies together with banks and financial institutions in 2010 is that, coming in the wake of the global financial crisis, one might reasonably have expected, not a sharp rise, but a sharp fall in confidence in such organisations. Compared with most other countries, however, Australian financial institutions and big business, with the help of a strong response from the federal government, came through the global financial crisis in a relatively strong position. Certainly, there were not the major institutional failures seen in other countries. The measures of citizen confidence in these data may well reflect public recognition of that situation. In a similar vein, the high levels of confidence evident in institutions of security - the military and the police - may reflect a desire for citizens to feel safe and protected in times of challenge and uncertainty.

\section{DIMENSIONS OF CONFIDENCE}

Next we consider the extent to which these individual items can be refined and combined for further analysis, focusing again on the 2010 data. Factor analysis is used to identify patterns of dimensionality, in particular to see whether certain individual items combine into thematically coherent groupings, which would allow for a more refined analysis. For example, does greater confidence in the federal government tend to coincide with greater confidence in political parties, parliament, the public service and the political system in general, so that we can talk about confidence in the institutions of politics as a whole? Eleven of the fourteen items prove amenable to such an analysis, in turn producing four distinct factors, as shown in Table 2 . The results in Table $\mathbf{2}$ are from a principal components analysis with varimax rotation and the coefficients presented are the

Table 2. Principal components analysis of confidence dimensions.

\begin{tabular}{|c|c|c|c|}
\hline & Politics & Media & Business \\
\hline \hline The federal government in Canberra & .86 & .13 & .07 \\
\hline Australian political parties & .80 & .17 & .17 \\
\hline The federal parliament & .89 & .10 & .10 \\
\hline The public service & .62 & .14 & .22 \\
\hline The Australian political system & .74 & .09 & .24 \\
\hline The press & .23 & .86 & .13 \\
\hline Television & .13 & .88 & .06 \\
\hline Major Australian companies & .23 & .10 & .01 \\
\hline Banks and financial institutions & .23 & .17 & .82 \\
\hline The armed forces & .02 & .00 & .01 \\
\hline The police & .22 & .10 & .07 \\
\hline Reliability (alpha) & .87 & .77 & .11 \\
\hline
\end{tabular}

Source: Australian Election Study, $2010(\mathrm{n}=2061)$. 
rotated factor loadings. The four factors in Table $\mathbf{2}$ can be labelled 'politics', 'media', 'business' and 'security'.

Five items load strongly on the first factor, namely the items measuring confidence in the government, political parties, parliament, the public service and the political system. This represents a highly reliable five-item scale, as indicated by the Cronbach's alpha reliability coefficient of .87. Turning to the second factor, the items for confidence in the press and television load strongly and again the reliability coefficient is high (.77). Likewise, the next factor has high loadings on the items measuring confidence in major Australian companies and banks and financial institutions and the alpha is .71. The fourth factor has high loadings for confidence in the armed forces and the police. This factor is not as distinct as the other three, however, and the alpha score is substantially lower (.51). This scale, depicting institutions of security, is clearly less reliable than the other three, but it is distinct enough and of sufficient substantive interest to make keeping it in the analysis worthwhile.

\section{SOCIO-POLITICAL DETERMINANTS OF CONFIDENCE}

The analysis now moves from the identification of dimensions of confidence to an exploration of the socio- political determinants of these attitude dimensions. First we create an additive scale for each dimension, generating four scales: one with five items representing politics, plus twoitem scales for confidence in the media, business and security. We then conduct an ordinary least squares (OLS) multiple regression analysis with each dimension, using the following set of independent variables: age, gender, education, occupation, income, employment status, trade union membership, religion, church attendance, region of residence, birthplace and political party identification. Table 3 presents the results.

Each column in Table $\mathbf{3}$ shows standardised partial regression coefficients (betas) from an OLS analysis in which each of confidence the dimensions is regressed on the independent variables. The $\mathrm{R}^{2}$ figure at the bottom of each column shows the total variation explained in each case. The first column in Table 3 lists the results of the analysis of confidence in political institutions. The first point to note is that the $\mathrm{R}^{2}$ is $7 \%$. In more detail, of the thirteen independent variables in the equation, only five register significant effects on confidence in political institutions. Thus, age has no significant effect on confidence in institutions of politics and neither does income, employment status, trade union

Table 3. Regression analysis of socio-political correlates of confidence in institutions (standardised regression coefficients).

\begin{tabular}{|c|c|c|c|c|}
\hline & \multicolumn{4}{|c|}{ Confidence in Institutions of: } \\
\hline & Politics & Media & Business & Security \\
\hline Gender (male) & $-.07 * *$ & $-.05 *$ & .02 & -.04 \\
\hline Age (years) & .01 & $-.10 * *$ & $.06 *$ & .04 \\
\hline University degree & $.06 *$ & -.01 & -.01 & -.03 \\
\hline White collar occupation & $.08 * *$ & -.03 & $.06 *$ & .04 \\
\hline Income & .03 & -.01 & $.11^{* *}$ & -.00 \\
\hline Self-employed & -.03 & -.03 & $-.10^{* *}$ & -.03 \\
\hline Governmentemployee & .02 & -.05 & -.00 & -.01 \\
\hline Trade union member & .04 & -.04 & -.03 & .01 \\
\hline \multicolumn{5}{|l|}{ Religion (ref: Catholic) } \\
\hline Protestant & -.01 & -.05 & .05 & $.07 *$ \\
\hline Other religion & -.02 & -.04 & .01 & $-.06^{*}$ \\
\hline No religion & .03 & -.06 & -.01 & -.06 \\
\hline Church attendance & $.08 * *$ & -.01 & .01 & .02 \\
\hline Urban residence & -.04 & .04 & -.02 & .00 \\
\hline Born outside Australia & .05 & .03 & .01 & $-.10^{* *}$ \\
\hline \multicolumn{5}{|l|}{ Party identification (ref: Lib.-Nat.) } \\
\hline Labor & $.12 * *$ & -.02 & $-.17 * *$ & -.02 \\
\hline Minor party & -.03 & $-.06 *$ & $-.12 * *$ & $-.13^{* *}$ \\
\hline No party id. & -.05 & $-.12 * *$ & $-.10^{* *}$ & $-.08 * *$ \\
\hline $\mathrm{R}^{2}$ & .07 & .04 & .07 & .06 \\
\hline
\end{tabular}

$* \mathrm{p}<.05 ; * * \mathrm{p}<.01$

Source: Australian Election Study, $2010(\mathrm{n}=2061)$. 
membership, religious denomination, birthplace, or region of residence. Three variables, union membership, government employee status and region of residence, do not significantly affect any of the four confidence dimensions.

The variables that do have significant effects on confidence in political institutions are gender, education, occupation, church attendance and political partisanship. Men are less likely to indicate confidence in political institutions than women. People who hold a university degree and those in a non-manual occupation express more confidence than those with a lower level of education or in a manual occupation. Greater confidence also coincides with more frequent church attendance. But the most distinctive influence is that of party identification (measured by a series of dummy variables). The set of coefficients near the bottom of the first column of Table 3 shows a clear division in political confidence along party lines, especially between the two major party groups. Compared to Liberal-National party identifiers (the omitted reference category) Labor partisans are decidedly more inclined to show confidence in the institutions of politics. The negative signs on the coefficients for minor party identifiers (mainly Greens) and those who have no party identification suggest that these respondents have even less confidence in political institutions than Liberal-National supporters. These findings reinforce earlier evidence that political confidence, and also the related concept of political trust, is stronger among supporters of the party in government than among supporters of other political parties (Bean 2001; 2003).

When we turn to look at confidence in media institutions, we see that these attitudes are not structured much at all by socio-demographic differences. Not only is the general level of confidence in these institutions low, it is consistently low from one social grouping to another. Only for gender, age and party identification do we see some modest differences in confidence. Again, males have less confidence than females; older people display less confidence than younger people; supporters of minor parties and non-identifiers are less confident in institutions of the media than those who identify with either major party. But there are no differences in the level of confidence shown in the media according to socio-economic status, religion, region of residence or ethnic origin. The verdict that media institutions do not inspire confidence seems to be widely shared among different sectors of the Australian public. Confidence in the institutions of business shows a different set of divisions. Age has an impact but in this case older respondents display more confidence than younger. Understandably, given social structural differences in the propensity to have financial investments in major companies, the main sociodemographic effects are along socio-economic status lines. Those in white collar occupations have more confidence than those in blue collar occupations. Income has a very clear impact, with higher income earners more likely to have confidence in institutions of commerce than those with lower incomes, which is consistent with evidence that financial investment through share ownership increases as income rises (White, Tranter and Hanson 2004). The self-employed are, interestingly, less likely to have confidence in major companies and banks than those who are not self-employed. Far from the glamorous image of self-employment as the preserve of those in positions of wealth, the reality of selfemployment is that it is probably more often associated with small business people for whom making a living is an ongoing struggle and for whom dealings with major companies and financial institutions is not always a positive experience.

The largest effects are for party identification. When it comes to confidence in business institutions, there is a clear partisan divide between supporters of the right of centre coalition parties and all other identifiers. The greater confidence evidenced by Liberal-National identifiers of course reflects the longstanding alignment between the coalition and big business. The biggest gap is between Labor and the Liberal-National identifiers, but supporters of minor parties and non-identifiers also clearly display less confidence in the institutions of commerce than coalition identifiers.

Similar to confidence in the media, few social divisions are apparent when it comes to confidence in institutions of security. Religion appears to play a role in shaping confidence in security institutions, such that members of Protestant denominations are more likely than Catholics to show confidence, while members of 'other' religions display less confidence. With Catholics coming in the middle, the gap between Protestants and adherents of other religions is thus quite substantial. Respondents not born in Australia have less confidence in the armed forces and the policethan the native born, which could reflect a lesser sense of commitment to the internal and external protection of Australia and Australians, or differing conceptions of respect for authority, or a combination of the two. Confidence in the institutions of security is also shaped by partisan considerations. As with confidence in the media, the divide is essentially between adherents of the two major parties and those who align with a minor party or who disavow a party affiliation altogether. Given the stance of minor parties like the Greens on issues of defence and border security, it is not surprising that supporters of such parties would have lower levels of confidence in security institutions than those who align with one or other of the major parties.

\section{DISCUSSION AND CONCLUSION}

A number of implications can be drawn from the findings in this paper, at both practical and theoretical levels. The base point for the discussion is the observation that the level of confidence in many institutions is quite low and only a few institutions - notably the armed forces, the police and universities - register consistently high levels of public confidence. The counterpoint, however, is that there is no ongoing trend towards decline in public confidence in institutions generally. The absence of a persistent downward trend in confidence is somewhat at odds with theoretical arguments that imply the likelihood of an inexorable decline in confidence in public institutions due to the increasing strains placed on them by weight of rising public expectations. On an international scale, at least a partial resolution may be that a decline in political confidence had already occurred prior to the time period under consideration, in the 1960s and 1970s, as some scholars have shown (Dalton 1999). Unfortunately, there are no data 
extending back beyond the 1980s with which to test this proposition for Australia.

In the years from 1983 to 2010 , a number of the institutions considered in this study suffered declines in confidence over some of the period, but there is no single case of unremitting decline. Even major Australian companies, in which confidence had declined progressively into the first decade of the $21^{\text {st }}$ century from a high base in the 1980s, registered a renewed level of confidence in 2010.This finding stands as something of a corrective to earlier work (Papadakis 1999; Bean 2003; 2005) which showed what seemed to be an inexorable decline in confidence in major companies. At the top end of the scale, the armed forces have experienced a growth in confidence in recent times. On the other hand, for political institutions, confidence has waxed and waned while for some other institutions confidence has not altered much over the years.

The evidence of increased confidence in 2010 in both financial and security organisations, in spite of the challenges of the era, is one of the more interesting revelations in these data. If these trends seem counterintuitive, a possible explanation is that in difficult times - in this instance times of terrorist threats and the global financial crisis - people tend to rally behind major institutions, wanting to feel a sense of confidence in the familiar. And, of course, in regard to banks and major companies, by 2010 we had come through the worst of the global financial crisis, with Australian banks and companies comparatively in fairly good shape.

Based on the findings of this analysis, there is little evidence of strong socio-demographic divisions in citizen confidence in institutions. Although traditional sociodemographic variables such as gender, age, education, occupation and income all register effects here and there, they are modest and not sustained. The most consistent effects are for party identification. Minor party supporters and those with no party affiliation repeatedly display less confidence in institutions than major party identifiers. There are also two cases in which the supporters of the opposing major parties are at odds with each other. Liberal-National identifiers are considerably more confident in the institutions of business than are Labor identifiers. Conversely, in 2010 Labor identifiers displayed more confidence than coalition identifiers in the institutions of politics. Reinforcing previous evidence on confidence and trust (Bean 2001; 2003), this latter finding reflects the tendency for supporters of the government in power to have more benign views of political institutions. A corollary of this finding is that when the party complexion of the government changes we can expect the possibility that substantial changes in patterns of citizen confidence in political institutions may accompany it.

Overall, the picture of trends in public confidence in institutions contains greater complexity than theories that would link them to ongoing declines in social capital or increased strains on regimes might assume. The picture is more one of ebbs and flows than of sustained movement upwards or downwards. In particular, assumptions that the pressures of the modern world and other associated developments will result in a continuing decline in public confidence are not supported by this analysis. In the case of some institutions, of course, this is because they have struggled to maintain public confidence over a long period of time and confidence has been at consistently low levels throughout the period of the study. Certain other institutions, however, appear to be able to maintain confidence through thick and thin.

Reflection on the meaning of these findings for democracy, political stability and the effectiveness of government in a stable political system like Australia's, leads to the conclusion that low political confidence does not necessarily imply looming instability or the undermining of democracy. Elsewhere it has been argued that low levels of political confidence can go hand in hand with strong support for democratic principles and that public dissatisfaction is often due to democratic processes not operating as well as they should (Dalton 1999). Ultimately, it would appear that citizens may be critical of the workings of their nation's political institutions in practice without fundamentally losing faith in democracy as a system of government per se.

\section{CONFLICT OF INTEREST}

The author confirms that this article content has no conflicts of interest.

\section{ACKNOWLEDGMENTS}

Declared none.

\section{REFERENCES}

Bean, C. (2001). Party politics, political leaders and trust in government in Australia. Political Science, 53(1), 17-27.

Bean, C. (2003). Citizen confidence in social and political institutions in a changing world. Proceedings of the social Change in the $21^{\text {st }}$ Century Conference. Brisbane.

Bean, C. (2005).Is there a crisis of trust in Australia? In S. Wilson, G. Meagher, R. Gibson, D. Denemark and M. Western (Eds.), Australian social attitudes: The first report (pp. 122-140). Sydney: UNSW Press.

Bean, C., Gow, D., \& McAllister, I. (2002). Australian election study, 2001: User's guide for the machine-readable data file. Canberra: Social Science Data Archives, Australian National University.

Birch, A.H. (1984). Overload, ungovernability and delegitimation: The theories and the British case. British Journal of Political Science, 14, 135-160.

Blunsdon, B., \& Reed, K. (2010). Confidence in Australian institutions 1983-2005. Australian Journal of Social Issues 45, 445-458.

Braithwaite, V., \& Levi, M. (Eds.).(1998). Trust and governance. New York: Russell Sage Foundation.

Burchell, D., \& Leigh, A. (Eds). (2002). The prince's new clothes: Why do Australians dislike their politicians? Sydney: UNSW Press.

Ciro, T. (2012). The global financial crisis: Triggers, responses and aftermath. Aldershot: Ashgate.

Dalton, R.J. (1999). Political support in advanced industrial democracies. In P. Norris (Ed.). Critical citizens: Global support for democratic governance (pp. 57-77). Oxford: Oxford University Press.

Inglehart, R. et al. (2000). World values surveys and European values surveys, 1981-1984, 1990-1993, and 1995-1997. Ann Arbor, MI: Institute for Social Research.

King, A. (1975). Overload: Problems of governing in the 1970s. Political Studies 23, 284-296.

Leigh, A. (2010). Disconnected. Sydney: University of New South Wales Press.

Lipset, S.M., \& Schneider, W. (1983). The confidence gap: Business, labor, and government in the public mind. New York: Free Press.

Martin, A. (2010). Does political trust matter? Examining some of the implications of low levels of political trust in Australia. Australian Journal of Political Science 45, 705-712. 
McAllister, I. (2014). Corruption and confidence in Australian political instituions. Australian Journal of Political Science 49, 174-185.

McAllister, I., Bean, C., Pietsch, J., \& Gibson, R. (2011). Australian election study, 2010: Codebook. Canberra: Australian Social Science Data Archive, Australian National University.

Norris, P., (Ed.). (1999). Critical citizens: Global support for democratic governance. Oxford: Oxford University Press.

Nye, J.S., Zelikow, P. D., \& King. D. C. (Eds.). (1997). Why people don't trust government. Cambridge.: Harvard University Press.

Papadakis, E. (1999). Constituents of confidence and mistrust in Australian institutions. Australian Journal of Political Science 34, 75-93.

Pharr, S.J., \& Putnam, R. D. (Eds.). (2000). Discontented democrats. Princeton, N.J: Princeton University Press.

Putnam, R.D. (2000). Bowling alone: The collapse and revival of American community. New York: Simon \& Schuster.
Rose, R., (Ed.). (1980). Challenge to governance: Studies in overloaded polities. Beverly Hills: Sage Publications.

Sykes, T. (2010). Six months of panic: How the global financial crisis hit Australia. Sydney: Allen \& Unwin.

Tranter, B., \& Western, M. (2003). Postmaterial values and age: The case of Australia. Australian Journal of Political Science 38, 239-257.

Warren, M.E., (Ed.).(1999). Democracy and trust. Cambridge: Cambridge University Press.

White, R., Tranter B., \&Hanson, D. (2004). Share ownership in Australia: The emergence of new tensions? Journal of Sociology, 40(2), 99120.

Wilson, S., Meagher, G., Gibson, R., Denemark, D., \& Western, M. (Eds.). (2005). Australian social attitudes: The first report. Sydney: UNSW Press.

(C) Clive Bean; Licensee Bentham Open.

This is an open access article licensed under the terms of the Creative Commons Attribution Non-Commercial License (http://creativecommons.org/licenses/by-nc/3.0/) which permits unrestricted, non-commercial use, distribution and reproduction in any medium, provided the work is properly cited. 